\title{
Evaluation of live microalgal diets for the seed culture of Ruditapes decussatus using physiological and biochemical
}

\section{parameters}

Marina Albentosa ${ }^{\mathrm{a},{ }^{*}}$, Alejandro Perez-Camacho ${ }^{\mathrm{a}}$, Uxio Labarta ${ }^{\mathrm{b}}$,

Maria Jose Fernandez-Reiriz ${ }^{\mathrm{b}}$

a Instituto Español de Oceanografia, Centro Oceanografico de La Coruña, Muelle de Animas, s/n. P.O. Box 130, E-15001 La Coruña, Spain

${ }^{\mathrm{b}}$ Consejo Superior de Investigaciones Cientificas, Instituto de Investigaciones Marinas, Eduardo Cabello, 6, E-36208 Vigo, Spain

* Corresponding author. Tel.: 34-81-205362; Fax: 34-81-229077

\section{Abstract}

The nutritional quality of several microalgal diets used in the seed culture of the littleneck clam, Ruditapes decussatus, was evaluated in the present study. The live diets tested were Isochrysis galbana, clone T-ISO, Tetraselmis suecica and Phaeodactylum tricornutum. Criteria used in the evaluation of the diets were acceptability, digestibility, growth and biochemical composition. The highest growth rate was registered in the seed fed the T. suecica diet, followed by the seed fed I. galbana, while the lowest one was obtained in the seed fed P. tricornutum. Food ingestion rates were higher in the seed fed Tetraselmis. This fact would partly explain the higher growth observed with this diet. The limited nutritional value of Phaeodactylum could be related to the low digestibility of its cell wall, the degree of acceptability of this diet being similar to or even higher than that of the other two. The low protein content of Tetraselmis seems to indicate that R. decussatus shows a low requirement for proteins, which can be spared by carbohydrate, an abundant component in the cells of Tetraselmis. Lipid needs of this bivalve also seem to be rather low.

Keywords: Ruditapes decusatus; Seed; Algal diets; Nutrition

1. Introduction 
Microalgae production as food for larvae, seed and broodstock conditioning is one of the most important operations in mollusc hatcheries (Coutteau and Sorgeloos, 1992). The majority of this production is dedicated to seed culture, which takes more than $50 \%$ of the total production.

The nutritional quality of the different species of microalgae used in the seed culture of some species of bivalves has been studied at length (among others: Walne (1970) on Ostrea, Crassostrea, Mercenaria and Mytilus; Epifanio (1979) on Crassostrea and Mercenaria; Enright et al. (1986) and Laing and Millican (1986) on Ostrea edulis; O'Connor et al. (1992) on Saccostrea commercialis). However, little is known about the nutritional value of different microalgae cultured for R. decussatus (Laing et al., 1987). It is a common practice in bivalve aquaculture to apply the same diet to all species being cultured, regardless of their specific nutritional requirements. The existence of important physiological differences between closely related bivalve species (Beiras et al., 1993; Albentosa et al., 1994) points out the need for special studies focussing on each of the cultured species. On the other hand, most studies only show the growth rates obtained with each diet, whereas the aspects which determine the nutritional quality of a diet, such as its degrees of acceptability, digestibility, and nutritional requirements are hardly taken into account.

In the present study, we have evaluated several monoalgal diets for the culture of the seed of Ruditapes decussatus, using a method which can explain differing growth rates in relation to both physiological (ingestion, absorption and growth efficiency) and biochemical parameters (biochemical composition of the food and its effects on the composition of the seed).The microalgae species tested were Isochrysis galbana, clone T-ISO, Tetraselmis suecica and Phaeodactylum tricornutum.

2. Materials and methods

\subsection{Seed}

Seed used in this experiment was obtained from Ruditapes decussatus broodstock conditioned at the Instituto Español de Oceanografia. Both spawning induction and larvae culture were carried out following the methodology described for this species by 
Perez-Camacho et al. (1977). Seed showed an initial size of $0.77 \pm 0.09 \mathrm{~mm} \mathrm{ind}^{-1}, 0.15$ $\pm 0.01 \mathrm{mg}$ live weight (LW) ind ${ }^{-1}, 0.08 \pm 0.01 \mathrm{mg}$ dry weight $(\mathrm{DW}) \mathrm{ind}^{-1}$ and the organic content was $14.50 \pm 0.01 \%$ of the dry weight (AFDW) (see below for methods). They were distributed at random among the different experimental culture vessels. Each vessel contained an initial biomass of $200 \mathrm{mg}$ (live weight).

\subsection{Experimental conditions of the seed cultures}

The culture was carried out in plastic vessels of 61 capacity, with the seed being placed on the bottom surface. A slight aeration was applied in order to minimize the sedimentation rate of the microalgae. The experimental cultures were placed in an isothermal room to keep water temperature at $20 \pm 1{ }^{\circ} \mathrm{C}$. The water was changed daily using seawater filtered at $1 \mu \mathrm{m}$ and run through UV. Cultures were kept for 4 weeks. Each diet was tested in triplicate, adding a fourth culture without animals in order to quantify the sedimentation rate of the food.

\subsection{Diets}

Three species of live microalgae were evaluated: Isochrysis galbana (clone-T-ISO), Tetraselmis suecica and Phaeodactylum tricornutum. The microalgae were cultured in 6 1 glass flasks, in an isothermal room at $18^{\circ} \mathrm{C}$ with continuous illumination at 9900 lux. Salinity was kept constant at 33\%o. The culture medium was as described by Walne (1966). The microalgae were harvested at the beginning of the stationary growth phase.

The daily feeding ration, applied to all diets and expressed as organic weight, was $2 \%$ of the live weight of the seed (Albentosa et al., in press). Microalgae concentrations in the cultures were measured using a Coulter particle counter. Initial food concentrations in the experimental cultures never exceeded 100 cells of Isochrysis $\mu 1^{-1}(=1.7 \mu \mathrm{g}$ organic matter $\mathrm{ml}^{-1}$ ), the concentration at which the highest ingestion rates of the seed had been recorded, according to results obtained in our laboratory (Albentosa et al., in press). The increase in biomass due to growth during the experiment was compensated for by adjusting the food ration and the volume of water in the seed vessels was increased weekly in order to keep the initial concentration of food constant. During the first week 
of the experiment, only one growth rate was considered for all diets, this being estimated from preliminary tests carried out in our laboratory.

Dry weight and organic content of the phytoplanktonic cells were calculated during the experiment by filtration through Whatman GF/C glass fiber filters which had been previously rinsed with $0.5 \mathrm{M}$ ammonium formate solution and then ashed at $450^{\circ} \mathrm{C}$. Filters were dried to constant weight at $100^{\circ} \mathrm{C}$, ashed at $450^{\circ} \mathrm{C}$ in a muffle furnace, and reweighed. Variations in algal weight during the experimental period were considered when daily food ration was calculated.

Samples from each of the diets fed during the four-week experimental period were collected for biochemical analyses. Samples were centrifuged, resuspended in $0.5 \mathrm{M}$ ammonium formate solution, freeze-dried and stored at $-30^{\circ} \mathrm{C}$ until analyzed.

\subsection{Evaluation parameters of diets}

Daily ingestion was calculated from the number of cells cleared in each experimental culture after each feeding period $(24 \mathrm{~h})$ by means of the following expression: $\mathrm{I}=$ $\mathrm{V} / \mathrm{n}\left[\left(\mathrm{C}_{\mathrm{eo}}-\left(\mathrm{C}_{\mathrm{eo}} * \mathrm{~S}_{\mathrm{ed}}\right)\right)-\mathrm{C}_{\mathrm{ef}}\right]$, where $\mathrm{I}$ is the ingestion expressed in cells ind ${ }^{-1} \mathrm{day}^{-1}, \mathrm{~V}$ is the volume of the seed culture $(\mathrm{ml}), \mathrm{n}$ is the number of clams, and Sed is the sedimentation rate which was calculated as: $\left(\mathrm{C}_{\mathrm{bo}}-\mathrm{C}_{\mathrm{bf}}\right) / \mathrm{C}_{\mathrm{bo}}$. Initial and final concentrations of the control culture (without animals) were noted as $\mathrm{C}_{\mathrm{bo}}$ and $\mathrm{C}_{\mathrm{bf}}$, and initial and final concentrations of the experimental cultures as $\mathrm{C}_{\mathrm{eo}}$ and $\mathrm{C}_{\mathrm{ef}}$, respectively.

Increases in live weight for each experimental culture were registered weekly, and at the end of the 4 week experimental period dry weight $\left(100^{\circ} \mathrm{C}, 24 \mathrm{~h}\right)$, organic content $\left(450^{\circ} \mathrm{C}, 24 \mathrm{~h}\right)$, and length of the seed were also determined. After these measurements, the remainder of the seed was used to perform the biochemical analyses. Growth observed during the experiment was adjusted to the equation Weight $=\mathrm{e}^{\alpha+\mathrm{kt}}$, where weight is expressed in $\mathrm{mg} \mathrm{ind}^{-1}$, time ( $\mathrm{t}$ ) in days and $\mathrm{k}$ and $\alpha$ are constants, $\mathrm{k}$ represents the slope of the line and has been taken to be the growth rate and has also been used as a comparative parameter for the growth between diets. 
Gross growth efficiency $\left(\mathrm{K}_{1}\right)$ was taken to be the proportion of organic matter ingested which is used in growth, according to the equation $\mathrm{K}_{1}=\mathrm{G} / \mathrm{I}$, where $\mathrm{G}$ is the increase in organic matter in the seed over a period of time and I is the quantity of organic matter ingested in the same period. Net growth efficiency $\left(\mathrm{K}_{2}\right)$ was estimated as the proportion of organic matter absorbed, since they are sexually immature animals the organic matter absorbed only includes the organic matter used in growth and that consumed in the respiration process, which is incorporated as organic matter in the seed, that is to say, $\mathrm{K}_{2}=\mathrm{G} /(\mathrm{G}+\mathrm{R})$, where $\mathrm{R}$ is the organic matter equivalent to oxygen consumption by the seed due to respiration. We considered the same respiration rate for all treatments, 2.45 $\mu \mathrm{g} 0_{2}(\mathrm{mg} \text { seed AFDW })^{-1} \mathrm{~h}^{-1}$, data obtained in our laboratory with seed of the same species and same size (Albentosa et al., in press).The following conversion factors have been used: $1 \mathrm{mg} 0_{2}$ equivalent to $0.6998 \mathrm{ml} \mathrm{0,} \mathrm{(Ansell,} \mathrm{1973)} \mathrm{and} 1 \mathrm{mg}$ AFDW equivalent to $1.2 \mathrm{ml} \mathrm{0}_{2}$ (Walne, 1965 cited by Laing and Millican, 1986). Absorption efficiency was estimated as the proportion of ingested organic matter which is absorbed, following the equation $\mathrm{AE}=(\mathrm{G}+\mathrm{R}) / \mathrm{I}$.

The efficiency of use of the dietary components was estimated following the expression $\mathrm{CRI}=\left(\mathrm{C}_{\mathrm{f}}-\mathrm{C}_{\mathrm{i}}\right) / \mathrm{C}_{\mathrm{ing}}$, where $\mathrm{CR} 1$ is the retention index for each component, $\mathrm{C}$ : proteins $\mathrm{P}$, carbohydrates $\mathrm{Ch}$, and lipids $\mathrm{L} ; \mathrm{C}_{\mathrm{i}}$ and $\mathrm{C}_{\mathrm{f}}$ are the contents for each of the major components in the seed at the beginning and end of the experiment, and $\mathrm{C}_{\text {ing }}$ is the quantity of dietary component which has been ingested during the experiment.

\subsection{Analytical methods}

Proteins were determined following \&he method of Lowry et al. (1951), after alkaline hydrolysis with $0.5 \mathrm{~N} \mathrm{NaOH}$ for $24 \mathrm{~h}$ at $30^{\circ} \mathrm{C}$. Total carbohydrates were quantified as glucose by means of the phenol-sulphuric method (Strickland and Parsons, 1968). Lipids were extracted by a modification of the Bligh and Dyer (1959) method (Fernandez-Reiriz et al., 1989): lipid material was extracted by means of chloroformmethanol (1:2); after centrifugation, the sediment was extracted again with chloroformmethanol (2:1). In order to purify the extract, both supernatants were washed with a mixture of chloroform, methanol and water (8:4:3:), following Folch et al. (1957). Total lipids were gravimetrically determined through evaporation of the solvent in the purified extract on aluminium sheets at $60-80^{\circ} \mathrm{C}$. 


\subsection{Statistical methods}

The results were analysed with the statistical package Statgraphics. Comparison between the different parameters of evaluation was carried out by an ANOVA with a level of signification of $\mathrm{P}<0.05$. Percent composition data and efficiencies were transformated by the angular transformation (arcsin $V_{\text {percentage }}$ ) prior to analysis to ensure normality. The homogeneity of variances was tested by means of the Bartlett test. Differences between each one of the treatments, in the case of multiple comparisons, were analysed using the Student-Newman-Keuls multiple range test. Comparison between regression lines was made by means of covariance analysis (Snedecor and Cochran, 1971; Zar, 1974).

\section{Results}

\subsection{Growth}

Seed growth was different depending on the diet supplied. The seed fed Tetraselmis reached a dry weight of $0.61 \pm 0.05( \pm$ s.d. $) \mathrm{mg} \mathrm{ind}^{-1}$ at the end of the experiment, those fed Isochrysis showed a final weight of $0.53 \pm 0.01 \mathrm{mg} \mathrm{ind}^{-1}$, and seed fed Phaeodactylum registered a final dry weight of $0.37 \pm 0.01 \mathrm{mg} \mathrm{ind}^{-1}$. Organic matter content was similar in all diets, between $12-15 \%$ of dry weight, and did not show significant differences.

Growth in live weight (LW) was exponentially related to time (t), as follows (Fig. 1):

$$
\begin{array}{lcccc}
\text { Isochrysis: } & \mathrm{LW}=\mathrm{e}^{-1.80+(0.069 \pm 0.003) \mathrm{t}} & \mathrm{r}=0.99 & \mathrm{P}<0.001 & \mathrm{n}=15 \\
\text { Tetraselmis: } & \mathrm{LW}=\mathrm{e}^{-1.86+(0.079 \pm 0.003) \mathrm{t}} & \mathrm{r}=0.99 & \mathrm{P}<0.001 & \mathrm{n}=15 \\
\text { Phaeodactylum: } & \mathrm{LW}=\mathrm{e}^{-1.83+(0.059 \pm 0.004) \mathrm{t}} & \mathrm{r}=0.98 & \mathrm{P}<0.001 & \mathrm{n}=15
\end{array}
$$

where LW is expressed in $\mathrm{mg}$ ind $^{-1}$ and $\mathrm{t}$ in days. Values in parentheses show the regression slopes or growth rates, $\mathrm{k}$, together with their standard errors. According to the covariance analyses, growth rates $(\mathrm{k})$, were significantly different $(\mathrm{P}<0.05)$ for each diet tested

\subsection{Ingestion}


The sedimentation rates of the three diets were very low (10\% for $24 \mathrm{~h})$. In spite of this, they were taken into account when calculating ingestion rates. The factor which most influenced the ingestion rate was the size of the seed; therefore, ingestion (I), expressed as $\mu \mathrm{g}$ AFDW ind $^{-1}$ day $^{-1}$, was related to the live weight of the seed, expressed as $\mathrm{mg}^{-}$ind $^{-}$ ${ }^{1}$, following the equations shown in Fig. 2a, Fig. 2b, Fig. 2c:

Isochrysis: $\quad \mathrm{IR}=\left(7.01 \pm 0\right.$ 52) $\mathrm{LW}^{(0.724 \pm 0.050)} \quad \mathrm{r}=0.86 \mathrm{P}<0.001 \mathrm{n}=75$

Tetraselmis: $\quad \mathrm{IR}=(10.96 \pm 0.06) \mathrm{LW}^{(0.833 \pm 0.055)} \quad \mathrm{r}=087 \mathrm{P}<0.001 \mathrm{n}=74$

Phaeoductylum: $\mathrm{IR}=(7.28 \pm 0.08) \mathrm{LW}^{(0.431 \pm 0.065)} \mathrm{r}=0: 65 \quad \mathrm{P}<0.001 \mathrm{n}=61$

The slopes of these regression lines were significatively different $(\mathrm{P}<0.05)$ depending on the diet. Differences were observed between Phaeodactylum on the one hand and between Isochrysis or Tetraselmis on the other. Between these last two there were no significant differences as far as slopes are concerned, although they were detected between intercepts.

\subsection{Efficiencies in the use of the diet}

Table 1 shows data for total ingestion, growth and respiration of the seed during the four week period, data which was used in the estimations of growth and absorption efficiencies. Both gross $\left(\mathrm{K}_{1}\right)$ and net $\left(\mathrm{K}_{2}\right)$ growth efficiencies and absorption efficiency were significantly different depending on the diet.

\subsection{Biochemical composition}

Data obtained from biochemical analyses of microalgae cultures used as food are shown in Table 2. With regard to major components, Isochrysis and Phaeodactylum cells presented a very similar composition, with a protein content of $15 \%$ of total organic matter, a carbohydrate content of between 20 and 30\% depending on the microalgae, and a similar lipid proportion, around $25 \%$ of total organic matter. On the contrary, Tetraselmis cells contained an appreciably lower content of protein and lipid, especially the latter, in comparison with the other two microalgae (13.8 and 11.9\%, respectively). However, the proportion of carbohydrate $(52.3 \%)$ was twice that recorded for the other two species (21.9\% in Isochrysis and $31.8 \%$ in Phaeodactylum). 
Table 3 shows the biochemical composition of the seed at the beginning and end of the experiment for all diets tested. The main components of the seed are protein, which account for approximately $30 \%$ of the total estimated organic matter. Carbohydrate content ranged between $20-23 \%$ and lipid content between $17-20 \%$. With regard to any of these major biochemical components, the variance analysis applied to the biochemical composition percent data of the seed does not show significant differences between diets.

Retention indices of the dietary components are shown in Fig. 3a-Fig. 3f, together with growth and ingestion data of each component used to calculate the retention indices. It can be observed that these indices vary according to diet, being inversely related to the composition of the food ingested. For example, in the seed fed Tetraselmis, a diet with a very low protein content (13.8\%) and a higher carbohydrate presence than in the other two diets $(52.3 \%)$, the highest protein retention index $(0.88)$ was recorded, whereas the same index for carbohydrate was rather low (0.21).

\section{Discussion}

According to the growth results obtained in this work, the microalga which shows a higher nutritional quality for the seed of R. decussatus was T. suecica, though the growth obtained with Isochrysis galbana was substantial. However, the nutritional quality of the microalgae Phaeodactylum for this bivalve was low.

In general, it is considered that the nutritional value of a microalgal species for bivalves is determined by the following factors: cell size, digestibility, toxicity and biochemical composition (Webb and Chu, 1983). Regarding cell size, all three microalgal species had a cell diameter suitable for the filtration mechanism of these animals (Jorgensen, 1990): $4.21 \pm 0.13$ for Isochrysis; $7.70 \pm 0.18$ for Tetraselmis and $4.52 \pm 0.11 \mu \mathrm{m} \mathrm{cel}^{-1}$ for Phaeodactylum. According to the results obtained, ingestion rates are in relation to growth rates, except for the case of the seed fed Phaeodactylum diet, which showed a total ingestion of $111.0 \mathrm{~kg}$ of organic matter ind $^{-1}$, in contrast to the seed fed Isochrysis, which had an ingestion of $102.9 \mu \mathrm{g} \mathrm{ind}^{-1}$. Taking into account that the size reached by the seed fed Isochrysis was higher than when fed Phaeodactylum, it can be stated that ingestion regarding seed size of Phaeodactylum diet was higher than that shown by 
Isochrysis. Therefore, differences observed in growth of seed fed these two microalgae cannot be explained by any difficulty in the ingestion of Phaeodactylum cells. On the contrary, the seed fed Tetraselmis showed a much higher total ingestion than the other two diets (168.6 $\left.\mu \mathrm{g} \mathrm{ind}^{-1}\right)$; moreover, ingestion rates regarding seed size were also higher in the seed fed on this microalgae than those observed in the seed fed on Isochrysis. Thus, one of the factors which may explain the higher nutritional quality of the microalga Tetraselmis in comparison to Isochrysis, would be the greater ingestion of the Tetraselmis cells.

The highest efficiency of food absorption was observed in the seed fed Isochrysis, followed by that fed Tetraselmis, whereas the lowest efficiency was obtained in the seed fed Phaeodactylum. The limited growth obtained with Phaeodactylum in this study, a fact described by other authors in other species of bivalves (Walne, 1970; Epifanio et al., 1981; Laing et al., 1987), could be explained by the fact that this microalga is difficult to digest. Epifanio (1983) studied the possible causes of its low nutritional value concluding, as is the case in this study, that its relative indigestibility is the most consistent factor to explain its nutritional quality. We have not observed digestibility problems in the seed fed Tetraselmis cells, though the absorption efficiency of this diet was appreciably lower (67.9\%) than that of Isochrysis (88.6\%). This is compensated for by a higher ingestion rate, and so the share of organic matter absorbed by the seed fed Tetraselmis was higher than that fed Isochrysis.

Growth rates shown in the seed fed Isochrysis were slightly lower than those registered in the seed fed Tetraselmis. Even so, we can consider Isochrysis, clone T-ISO, as a good food for the seed of R. decussatus. Since Ewart and Epifanio (1981) began their studies on this variety of I. galbana for its use in the culture of larvae and juveniles of Crassostrea virginica, many authors have used this microalga as food for bivalves and its suitability has already been proved, among others, for juveniles of Ostrea edulis (Enright et al., 1986; Laing and Millican, 1986), larvae (Helm and Laing, 1987), juveniles of Mercenaria mercenaria and Tapes semidecussata (Laing et al., 1987) and seed of V. pullastra (Albentosa et al., 1993).

Another possible explanation that accounts for differences in the nutritional quality of microalgae species is related to their biochemical composition. From this point of view, 
at least in the case of macronutrients, both Isochrysis and Phaeodactylum present a very similar biochemical composition, and therefore this factor would not explain the different growth rates obtained with each of these diets. The higher growth rate observed in the seed fed Tetraselmis, a microalga rich in carbohydrate in detriment of protein and lipid contents, allows us to suggest that the protein requirement of the seed of R. decussatus must be very low. Taking into account that the protein retention index of the seed fed this diet was the highest $(0.88)$ - i.e. that $88 \%$ of the protein ingested was used in the formation of new corporal structures, thus showing a high protein absorption efficiency- we can place the minimum protein need for the seed of this bivalve at around $14 \%$ of the total organic matter of the diet (Table 2). Therefore, the seed of R. decussatus is not only able to grow optimally with low protein content diets, but also the efficiency in the use of proteins of these diets is higher than in protein-rich ones (PRI = 0.81 for Isochrysis and 0.61 for Phaeodactylum). On the other hand, the low lipid content shown by Tetraselmis indicate that the seed of R. decussatus can mainly use carbohydrates as a source of energy when there is a low contribution of dietary lipids. In fact, the retention index of carbohydrates was very low $(0.21)$, and this could be related to the use of carbohydrates as a source of energy for growth, the retention indices for protein $(0.88)$ and lipids $(0.63)$ being much higher. To summarise, carbohydrates, which are present in considerable amounts in Tetraselmis (52.3\%), could replace part of the protein and lipid in the diet. The latter two are more abundant for example in Isochrysis, a diet which produces an high growth rate. It would therefore appear that R. decussatus seed adjusts its metabolism according to the biochemical composition of the diet, with the biochemical profile of the seed at the end of the experimental period being independent of the diet. It should be pointed out that we are talking about sexually immature individuals, in which there is no accumulation of reserves regarding reproduction, and therefore all the energy absorbed is dedicated to the maintenance and growth of the animal.

According to the results obtained from our work group (Albentosa et al., 1993), the nutritional quality of Tetraselmis for the seed of V. pullastra is very low due, among other factors, to it being difficult to digest, a fact already stated for other bivalve species (Epifanio (1979); Romberger and Epifanio (1981) with juveniles of C. virginica and M. mercenaria), although it has not been observed in the present study with R. decussates seed. The hypotheses presented in this discussion concerning the nutritional 
requirements of $\mathrm{R}$. decussatus contrast with those presented for $\mathrm{V}$. pullastra (Albentosa et al., 1993). The fact that Tetraselmis is an excellent diet for R. decussatus, but poor food for V. pullastra, may be connected with inferred differences in the nutritional requirements of both bivalve species. Furthermore, the biochemical composition of the seed of both clams is essentially different (Albentosa et al. (1993) for V. pullastra and present data for R. decussatus). From our point of view, this fact strengthens the hypothesis that the nutritional requirements of both species must be different. Therefore, the existence of important physiological (Albentosa et al., 1994) and biochemical differences (Albentosa et al., 1993) between these two close species of bivalves shows the importance of carrying out studies for each of the species being cultured, and stresses the need for not extrapolating the results that have been obtained on one species to others, an all too frequent practice when dealing with their aquaculture. Moreover, the joint use of physiological and biochemical parameters such as those applied in this study allow us to determine those factors which condition the nutritional quality of a diet; factors which can differ according to the species of bivalve.

\section{Acknowledgements}

We would like to thank C. Fernandez Pena for her technical assistance in microalgal and seed cultures and L. Nieto and B. Gonzalez for the biochemical analyses. This study has been financed by CICYT-CSIC-IEO I + D project MAR90-0812-C02-01.

\section{References}

Albentosa, M., Perez-Camacho, A., Labarta, U., Beiras, R. and Fernandez-Reiriz, M.J., 1993. Nutritional value of algal diets to clam spat Venerupis pullastra. Mar. Ecol. Prog. Ser., 97: 261-269.

Albentosa, M., Beiras, R. and Perez-Camacho, A., 1994. Determination of optimal thermal conditions for growth of clam (Venerupis pullastra seed. Aquaculture, 126: 315-328.

Albentosa, M., Perez-Camacho, A. and Beiras, R. (in press). The effect of food concentration on the scope for growth and growth performance of Ruditapes decussatus seed reared in an open-flow system. Aquaculture Nutrition. 
Ansell, A.D., 1973. Oxygen consumption by the bivalve Donax vittatus (da Costa). J. Exp. Mar. Biol. Ecol., 11: 311-328.

Beiras, R., Perez-Camacho, A. and Albentosa, M., 1993. Influence of food concentration on energy balance and growth performance of Venerupis pullastra seed reared in an open- flow system. Aquaculture, 116: 353-365.

Bligh, E.G. and Dyer, W.J., 1959. A rapid method of total lipid extraction and purification. Can. J. Biochem. Physiol., 37: 911-917.

Coutteau, P. and Sorgeloos, P., 1992. The use of algal substitutes and the requirements for live algae in the hatchery and nursery rearing of bivalve molluscs: an international survey. J. Shellf. Res., 11(2): 467-476.

Enright, CT., Newkirk, G.F., Craigie, J.S. and Castell, J.D., 1986. Evaluation of phytoplankton as diets for juvenile Ostrea edulis L. J. Exp. Mar. Biol. Ecol., 96: 113.

Epifanio, C.E., 1979. Growth in bivalve molluscs: nutritional effects of two or more species of algae in diets fed to the American oyster Crassostrea virginica (Gmelin) and the hard clam Mercenaria mercenaria CL.). Aquaculture, 18: 1-12.

Epifanio, C.E., 1983. Phytoplankton and yeast as foods for juvenile bivalves: a review of research at the University of Delaware. In: G.D. Pruder and C. Langdon (Editors), Biochemical and Physiological Approaches to Shellfish Nutrition, Proc. 2nd International Conference on Aquaculture Nutrition, 1981, pp. 292-304.

Epifanio, C.E., Valenti, C.C. and Turk, C. L., 1981. A comparison of Phaeodactylum tricornutum and Thalassiosira pseudonana as foods for the oyster, Crassostrea virginica. Aquaculture, 23: 347-353.

Ewart, J.W. and Epifanio, C.E., 1981. A tropical flagellate food for larval and juvenile oysters, Crassostrea virginica Gmelin. Aquaculture, 22: 297-300.

Fernandez-Reiriz, M.J., Perez-Camacho, A., Ferreiro, M.J., Blanco, J., Planas, M., Campos, M.J. and Labarta, U., 1989. Biomass production and variation in the biochemical profile (total protein, carbohydrates, RNA, lipids and fatty acids) of seven species of marine microalgae. Aquaculture, 83: 17-37.

Folch, J., Lees, M. and Sloane-Stanley, G.G., 1957. A simple method for the isolation and purification of total lipids from animal tissues. J. Biol. Chem., 226: 497.

Helm, M.M. and Laing I., 1987. Preliminary observations on the nutritional value of 'Tahiti Isochrysis' to bivalve larvae. Aquaculture, 62: 281-288. 
Jorgensen, C.B., 1990. Bivalve Filter Feeding: Hydrodinamics, Bioenergetics, Physiology and Ecology. Olsen \& Olsen, Denmark, 140 pp.

Laing, 1. and Millican, P.F., 1986. Relative growth and growth efficiency of Ostrea edulis spat fed various algal diets. Aquaculture, 54: 245-262.

Laing, I., Utting, S.D. and Kilada, R.W.S., 1987. Interactive effect of diet and temperature on the growth of juvenile clams. J. Exp. Mar. Biol. Ecol., 113: 23-38.

Lowry, O.H., Rosebrough, N.H. and Fair, A.L., 1951. Protein measurement with the pholin-phenol reagent. J. Biol. Chem., 193: 265-275.

O’Connor, W.A., Nell, J.A. and Diemar, J.A., 1992. The evaluation of twelve algal species as food for juvenile Sydney rock oysters Saccostrea commercialis (Iredale \& Roughley). Aquaculture, 108: 277-283.

Perez-Camacho, A., Roman, G. and Terre Cervigon. M. 1977. Experiencias en cultivos de larvas de tres especies de moluscos bivalvos: Venerupis pullastra (Montagu), Venerupis decussata (Linnaeus) y Ostrea edulis (Linnaeus). Bol. Inst. Espa. Oceano., III(235): 7-62.

Romberger, H.P. and Epifanio, C.E., 1981. Comparative effects of diets consisting of one or two algal species upon assimilation efficiencies and growth of juvenile oysters, Crassostrea virginica (Gmelin). Aquaculture, 25: 77-87.

Snedecor, G.W. and Cochran, W.G., 1971. Metodos estadisticos. Continental S.A., 703 pp.

Strickland, J.D. and Parsons, T.R., 1968. A practical handbook of seawater analysis. Bull. Fish. Res. Bd. Can., 167 pp.

Walne, P.R., 1966. Experiments in the large-scale culture of the larvae of Ostrea edulis L. Fish. Invest. Minist. Agric. Fish. Food (GB) Ser. II., XXV (4). 53 pp.

Walne, P.R., 1970. Studies on the food value of nineteen genera of algae to juvenile bivalves of the genera Ostrea, Crasostrea, Mercenaria and Mytilus. Fish. Invest. Minist. Agric. Fish. Food (GB) Ser. II., XXVI (5), 62

Webb, K.L. and Chu, F.E., 1983. Phytoplankton as a food source for bivalve larvae. In: G.D. Pruder and C. Langdon (Editors), Biochemical and Physiological Approaches to Shellfish Nutrition. Proc. 2nd International Conference on Aquaculture Nutrition, 1981, pp. 272-291.

Zar, J.H., 1974. Biostatistical Analysis. Prentice-Hall, London. 
Fig. 1. Growth curves of Ruditapes decussatus seed fed the three live microalgal diets: Isochrysis galbana, clone T-ISO, Tetraselmis suecica and Phaeodactylum tricornutum. Data were fit to the equation: $\mathrm{LW}=\mathrm{e}^{\alpha+\mathrm{kt}}$, where $\mathrm{LW}$ is the live weight expressed as $\mathrm{mg}$ ind $^{-1}, \mathrm{t}$ is the time expressed as days and $\alpha$ and $\mathrm{k}$ (growth rate) are constants.

Fig. 2. Ingestion rates (IR, expressed as $\mu \mathrm{g} A F D W$ ind $^{-1}$ day $^{-1}$ ) of the seed of Ruditapes decussatus in relation to the size of the seed ( $\mathrm{LW}$, live weight, expressed as $\mathrm{mg} \mathrm{ind}^{-1}$ ) fed on three live microalgal diets: 1sochrysis galbana, clone T-IS0 (Fig. 2a), Tetraselmis suecica (Fig. 2b) and Phaeodactylum tricornutum (Fig. 2c). See text for calculations.

Fig. 3. Retention indices of the biochemical components of the diet (Fig. 3d, Fig. 3e, Fig. 3f) and growth and ingestion (Fig. 3a, Fig. 3b, Fig. 3c) of each of the biochemical components of the seed of R. decussatus fed on three live microalgal diets: Isochrysis galbana, clone T-ISO, Tetraselmis suecica and Phaeodactylum tricornutum. See text for calculations. 
Table 1

Gross $(\mathrm{K}$, ) and net $(\mathrm{K}$, ) growth efficiencies and absorption efficiency (AE) of the Ruditapes decussatus seed fed different microalgal diets: Isochrysis galbana, clone T-ISO, Tetraselmis suecica and Phaeodactylum tricornutum

\begin{tabular}{|c|c|c|c|c|c|c|}
\hline Diet & Ingestion $\left(\mu \mathrm{g}\right.$ AFDW ind $\left.^{-1}\right)$ & Growth $\left(\mu \mathrm{g}\right.$ AFDW ind $\left.^{-1}\right)$ & Respiration $\left(\mu \mathrm{g}\right.$ AFDW ind $\left.^{-1}\right)$ & $\mathrm{K}_{1}(\%)$ & $\mathrm{K}_{2}(\%)$ & $\mathrm{AE}(\%)$ \\
\hline I. galbana & $102.9 \pm 4.4$ & $56.5 \pm 1.8$ & $34.7 \pm 0.2$ & $54.9 \pm 1.2$ & $62.0 \pm 0.7$ & $88.6 \pm 2.5$ \\
\hline T. suecica & $168.6 \pm 16.6$ & $75.6 \pm 5.1$ & $38.5 \pm 1.5$ & $44.9 \pm 1.3$ & $66.2 \pm 0.7$ & $67.9 \pm 2.7$ \\
\hline P. tricornutum & $111.0 \pm 5.6$ & $35.3 \pm 6.1$ & $27.9 \pm 0.1$ & $31.8 \pm 4.8$ & $55.6 \pm 4.6$ & $56.9 \pm 4.6$ \\
\hline
\end{tabular}

Data are the average values of the three replicates and standard deviations are also shown.

Table 2

Biochemical composition of the microalgae used as food for Ruditapes decussatus seed: Isochrysis galbana, Tetraselmis suecica and Phaeodactylum tricornutum

\begin{tabular}{|c|c|c|c|c|c|c|c|c|c|}
\hline \multirow[t]{2}{*}{ Diet } & \multirow[t]{2}{*}{ Cellular volume $\left(\mu \mathrm{m}^{3}\right)$} & \multirow[t]{2}{*}{ DW (Pg) } & \multirow[t]{2}{*}{ AFDW (Pg) } & \multicolumn{2}{|c|}{ Protein } & \multicolumn{2}{|c|}{ Carbohydrate } & \multicolumn{2}{|c|}{ Lipid } \\
\hline & & & & (pg) & (\%AFDW) & (pg) & (\%AFDW) & (pg) & (\%AFDW) \\
\hline I. galbana & 40.9 & 17.5 & 16.7 & 3.0 & 17.7 & 3.7 & 21.9 & 4.8 & 28.8 \\
\hline T. suecica & 277.5 & 199.3 & 185.6 & 25.6 & 13.8 & 97.1 & 52.3 & 22.1 & 11.9 \\
\hline P. tricornutum & 52.7 & 30.6 & 26.4 & 4.2 & 15.9 & 8.4 & 31.8 & 6.7 & 25.3 \\
\hline
\end{tabular}

Data are expressed as $\mathrm{pg} \mathrm{cell}^{-1}$ and as the relative percentage of the total organic matter estimated by ashing (AFDW). Cell size and weights of the microalgae have been included in the table. 
Table 3

Biochemical composition of the Ruditapes decussatus seed fed for 4 weeks on different microalgal diets: Isochrysis galbana, T-ISO, Tetraselmis suecica and Phaeodactylum tricornutum

\begin{tabular}{|c|c|c|c|c|c|c|c|c|}
\hline \multirow[t]{2}{*}{ Diet } & \multirow{2}{*}{$\begin{array}{l}\text { DW } \\
\text { mg ind }^{-1}\end{array}$} & \multirow{2}{*}{$\begin{array}{l}\text { AFDW } \\
\text { mg ind }^{-1}\end{array}$} & \multicolumn{2}{|l|}{ Protein } & \multicolumn{2}{|c|}{ Carbohydrate } & \multicolumn{2}{|l|}{ Lipid } \\
\hline & & & $\mu \mathrm{g}$ ind $^{-1}$ & \%AFDW & $\mu \mathrm{g}$ ind $^{-1}$ & $\%$ AFDW & $\mu \mathrm{g}$ ind $^{-1}$ & \%AFDW \\
\hline Initial & 0.08 & 0.012 & 4.7 & 38.3 & 2.0 & 16.4 & 2.3 & 18.7 \\
\hline T. suecica & $0.61 \pm 0.05$ & $0.088 \pm 0.005$ & $25.2 \pm 2.3$ & $28.7 \pm 1.7$ & $20.3 \pm 2.0$ & $23.1 \pm 1.6$ & $14.8 \pm 1.4$ & $16.8 \pm 1.0$ \\
\hline $\begin{array}{l}\mathrm{P} . \\
\text { tricornutum }\end{array}$ & $0.37 \pm 0.01$ & $0.048 \pm 0.006$ & $15.4 \pm 2.4$ & $32.4 \pm 1.8$ & $11.2 \pm 3.8$ & $22.4 \pm 5.1$ & $8.1 \pm 0.7$ & $17.0 \pm 0.8$ \\
\hline
\end{tabular}

Mean data from the three replicates per each diet ( \pm s.d.) are shown as $\mu \mathrm{g} \mathrm{ind}^{-1}$ and as the relative percentage of the total organic matter estimated by ashing (AFDW). 